\title{
MEMBANGUN METODE IDENTIFIKASI LONGSOR BERBASIS FOTO UDARA FORMAT KECIL DI DAS BOMPON, MAGELANG, JAWA TENGAH
}

\author{
Heni Masruroh ${ }^{1}$, Junun Sartohadi², dan Anggri Setiawan ${ }^{3}$
}

Pasca Sarjana ${ }^{1}$, Fakultas Geografi, ${ }^{2,3}$, Universitas Gadjah Mada, Yogyakarta, Indonesia

henimasruroh@rocketmail.com

Diterima : Desember 2015; Direvisi : Juni 2016; Dipubikasikan: September 2016

\begin{abstract}
ABSTRAK Tujuan penelitian ini adalah (1) membangun metode interpretasi foto udara format kecil untuk identifikasi longsor di DAS Bompon; (2) melakukan pemetaan kerawanan longsor berbasis hasil interpretasi foto udara format kecil dan berbasis analisis DEM TerraSAR.Metode penelitian yang digunakan yaitu (1) identifikasi longsor berdasarkan interpretasi foto udara format kecil secara visual 0n-screen 2D dengan teknik langkah demi langkah (stepwise method); (2) penyusunan peta kerawanan longsor menggunakan metode Frequency Ratio (FR). Hasil penelitian menunjukkan bahwa foto udara format kecil berdasarkan kenampakan objek dapat digunakan untuk identifikasi longsor. Teknik identifikasi longsor menggunakan teknik langkah demi langkah (stepwise method). Identifikasi longsor menggunakan teknik langkah demi langkah dilakukan secara sistematis dan tidak dapat dibolak balik berdasarkan kenampakan objek pada foto udara format kecil. Kenampakan objek foto udara format kecil untuk identifikasi longsor, yaitu: $i$ ) tutupan lahan, $i$ i) bidang gawir longsor, $i i i)$ bentuk longsor, $i v$ ) erosi parit, $v$ ) asosiasi jalan dan $v i$ )asosiasi sungai. Unsur interpretasi yang digunakan untuk identifikasi longsor, yaitu: rona/warna, bentuk, asosiasi, pola, bayangan, dan tinggi. Hasil uji akurasi inventori longsor berdasarkan interpretasi foto udara format kecil dengan inventori longsor survei lapangan, yaitu $90 \%$. Persentase kelas kerawanan tinggi (27.43\%), kelas kerawanan sedang (52.13\%) dan kelas kerawanan rendah (20.44\%). Nilai uji validitas peta kerawanan longsor menggunakan success rate, yaitu $74 \%$.
\end{abstract}

Kata kunci: foto udara format kecil; kerawanan; kunci interpretasi; longsor.

ABSTRACT The purpose of this study are (1) developing method of small format aerial photograph for landslide identification in the Bompon Catchment; (2) conduct landslide susceptibility mapping based on result of small format aerial photograph interpretation and based on Geomorfometri analysis of TerraSAR DEM. The method which used are (1) landslide identification based on small format aerial photograph interpretation using visual interpretation on screen $2 D$ and step by step technique (stepwise method); (2) constructing of landslide susceptibility map using Frequency Ratio (FR). The result shows that small format aerial photograph can be used to landslide identification based on object appearance in the small format aerial photograph. The technique which used to landslide identification is using step by step method (stepwise method). Identification landslide using stepwise method cannot be inverted each other based on object appearance in small format aerial photograph. The object appearances which used to landslide identification are i) landover, ii) escarpment, iii) form of landslide, iv) gully erosion, v) road association and vi) river association. The element of interpretation which used are hue / color, shape, association, patterns, shadows, and height.Landslide inventory accuracy based on small format aerial photograph interpretation and landslide inventory based on field survey is $90 \%$. The percentage of high landslide susceptibility is around (27.43\%), the percentage of moderate landslide susceptibility classes is around (52.13\%) and the percentage of low landslide susceptibility landslide is around (20.44\%). The value of landslide susceptibility validity using success rate is $74 \%$.

Key words: small format aerial photograph; susceptibility; interpretation; landslide.

\section{PENDAHULUAN}

Tanah longsor merupakan bencana yang sering terjadi di Indonesia. Selama periode 2011-2015 telah terjadi 850 kejadian bencana tanah longsor di Indonesia (BNPB, 2015). Menurut Sartohadi (2008), jumlah kejadian bencana tanah longsor tertinggi di Indonesia terjadi pada wilayah yang memiliki topografi yang curam dan memiliki curah hujan $2000 \mathrm{~mm} /$ tahun.

Jawa merupakan salah satu Pulau di Indonesia yang memiliki kerawanan tinggi terhadap bencana tanah longsor. Selama periode 1990-2005 bencana tanah longsor yang terjadi di Jawa menyebabkan beberapa kerugian diantaranya 1.112 Jiwa meninggal, 8.682 rumah mengalami kerusakan, dan kerugian ekonomi mencapai 18.040.450 \$ (Hadmoko dkk., 2010). Jawa Tengah merupakan salah satu Provinsi di Pulau Jawa yang memiliki kerawanan tinggi terhadap bencana tanah longsor. Menurut Marfai dkk. (2007) telah terjadi 57 kejadian bencana tanah longsor di Provinsi Jawa Tengah selama periode tahun 2000-2007.

DAS Bompon terletak di dua Kecamatan, yaitu Kecamatan Salaman dan Kajoran, Kabupaten Magelang, Provinsi Jawa Tengah. DAS Bompon memiliki kerawanan tinggi terjadi bencana tanah longsor. DAS Bompon merupakan area perbukitan dengan kondisi kelerengan yang bervariasi. Pada tahun 2011, telah terjadi 12 kali bencana longsor lahan di Dusun Kalisari, Dusun Tubansari, dan Dusun Sabrang 
yang merupakan bagian dari DAS Bompon. Elemen risiko longsor di DAS Bompon yang pernah terjadi berupa rumah, kerusakan jalan dan lahan pertanian (Gambar 1).

Fokus penelitian ini yaitu membangun metode interpretasi foto udara format kecil untuk identifikasi longsor dan analisis pemetaan kerawanan longsor berbasis hasil interpretasi foto udara format kecil dan analisis geomorfometri DEM TerraSAR. Hasil penelitian berupa metode interpretasi foto udara format kecil untuk identifikasi longsor dan peta kerawanan longsor berbasis hasil interpretasi foto udara format kecil dan analisis geomorfometri DEM TerraSAR. Hasil penelitian menggunakan skala 1:10.000, sehingga informasi yang dihasilkan merupakan informasi yang detil. Hasil lain dari penelitian yaitu sebagai bahan pertimbangan prioritas konservasi dan mitigasi untuk pengurangan risiko longsor di DAS Bompon.

DAS Bompon memiliki morfologi berupa perbukitan. DAS Bompon memiliki ketebalan tanah lebih dari 4 meter, rendah bahan organik, material penyusun dasar dan permukaan berupa klei dan terdapat material alterasi hasil dari proses intrusi. Kenampakan fisik DAS Bompon dipengaruhi oleh aktifitas manusia berupa pembukaan lahan pertanian berupa kebun campuran dan tanaman musiman di lereng-lereng yang memiliki perbedaan kemiringan. Aktifitas manusia yang mempengaruhi kenampakan fisik DAS Bompon berupa pemotongan lereng yang digunakan untuk jalan dan rumah. Aktifitas manusia berupa pembukaan lahan pertanian dan pemotongan lereng menyebabkan lereng tidak stabil, sehingga mempengaruhi intensitas terjadinya tanah longsor.

Berdasarkan pencapaian penelitian, peta kerawanan longsor sebagian besar menggunakan skala kecil hingga menengah, sehingga geo informasi kerawanan longsor yang disajikan kurang memiliki tingkat akurasi yang tinggi. Berdasarkan pencapaian penelitian, identifikasi longsor aktual yang digunakan untuk pembuatan kerawanan longsor menggunakan metode survei dan pengukuran lapangan. Penginderaan jauh sebagai ilmu yang mempelajari kenampakan permukaan bumi tanpa kontak langsung dengan objek belum banyak dilakukan untuk kajian kerawanan longsor.
Manurut Carara et al. (1995) data penginderaan jauh merupakan data yang dapat dimanfaatkan untuk identifikasi longsor dan analisis kerawanan longsor. Penggunaan data penginderaan jauh untuk inventori longsor merupakan metode yang efektif, namun belum banyak dilakukan. Menurut Nichol et al. (2006), Fiorucci et al. (2011), Van Westen (1996) longsor dapat diidentifikasi melalui foto udara. Identifikasi longsor melalui interpretasi foto udara dapat dilakukan secara heuristik, yaitu berdasarkan pengalaman interpreter. Menurut Panizza (1996) kejadian sekarang dan masa lalu adalah kunci untuk masa depan, sehingga identifikasi longsor yang diperoleh dari interpretasi foto udara dapat dijadikan sebagai acuan dalam penentuan kerawanan longsor yang akan datang.

Pencapaian penelitian mengenai identifikasi longsor berdasarkan foto udara format kecil belum banyak dilakukan. Membangun metode interpretasi foto udara format kecil untuk identifikasi longsor merupakan salah satu pengembangan penggunaan data penginderaan jauh untuk identifikasi longsor dan analisis kerawanan longsor. Terdapat beberapa pencapaian penelitian penggunaan data penginderaan jauh untuk identifikasi longsor skala detil. Nichol et al. (2006) menggunakan kombinasi foto udara dengan citra satelit untuk mendeteksi longsor secara detil. Penelitian serupa juga dilakukan oleh Fiorucci et al. (2011) dan (Strozzi et al., 2013). Berdasarkan penelitian Fiorucci et al. (2011) dan Strozzi et al. (2013), data penginderaan jauh dapat digunakan sebagai pengindentifikasian longsor dan data inventori longsor. Berdasarkan penelitian Van Westen (1996), foto udara format kecil dapat digunakan sebagai identifikasi longsor, namun dalam penelitian tersebut belum menjelaskan kunci interpretasi untuk identifikasi keaktifan, tipologi longsor, belum menjelaskan secara detil dan sistematis metode interpretasi yang digunakan.

Berdasarkan fokus penelitian dan pencapaian penelitian maka penelitian ini memiliki tujuan: (1) menyusun metode interpretasi foto udara format kecil untuk identifikasi longsor skala 1:10.000; (2) pemetaan kerawanan longsor berbasis hasil interpretasi foto udara format kecil dan berbasis analisis geomorfometri DEM TerraSAR. 


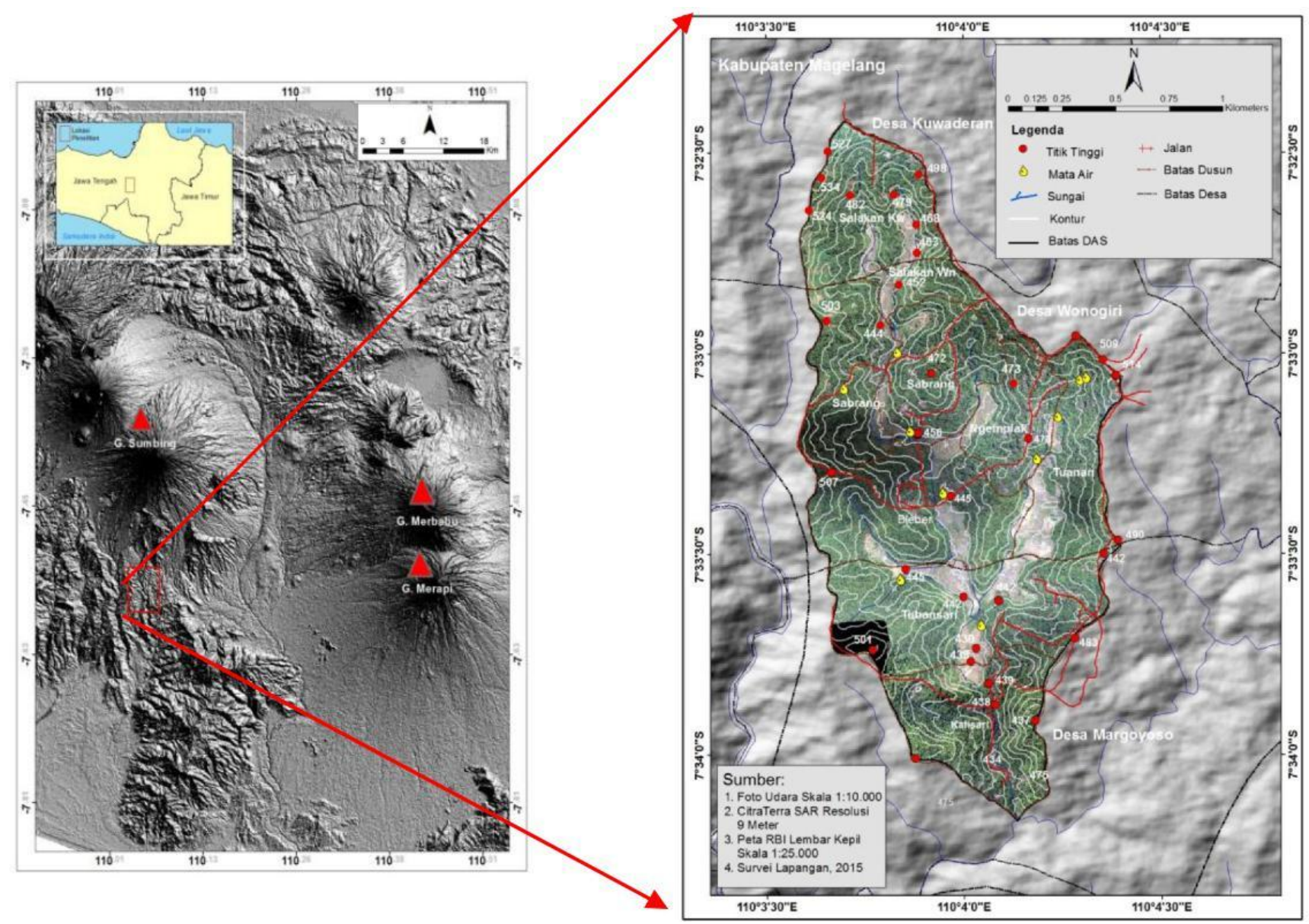

Gambar 1. Lokasi Penelitian

\section{METODE PENELITIAN}

Metode penelitian yang digunakan dalam penelitian ini yaitu metode interpretasi foto udara format kecil dan di dukung survei lapangan sebagai uji akurasi hasil interpretasi. Metode interpretasi foto udara format kecil dilakukan melalui sembilan unsur interpretasi untuk mengindetifikasi luasan longsor, tipologi longsor, keaktifan longsor dan tutupan lahan di daerah penelitian. Hasil interpretasi foto udara format kecil digunakan sebagai parameter pemicu longsor untuk menyusun peta kerawanan longsor (Tabel 1). Parameter pemicu longsor juga diperoleh berdasarkan analisis geomorfometri DEM TerraSAR.

Peta kerawanan longsor diperoleh menggunakan metode Frequency Ratio (FR) yaitu perbandingan luasan longsor pada setiap parameter kerawanan longsor. Parameter hasil interpretasi foto udara format kecil analisis geomorfomtri DEM TerraSAR yang digunakan yaitu longsor aktual, tutupan vegetasi, jarak longsor dengan sungai, kemiringan, ketinggian, bentuk lereng, Topographic Position Index (TPI), Plan Curvature, Profile Curvature, dan Compound Topograhic Index (CTI).
Tabel 1. Data Penelitian

\begin{tabular}{cll}
\hline No & \multicolumn{1}{c}{ Parameter } & \multicolumn{1}{c}{ Sumber } \\
\hline 1 & Longsor Aktif & $\begin{array}{l}\text { Foto Udara Format } \\
\text { Kecil }\end{array}$ \\
& & $\begin{array}{l}\text { Foto Udara Format } \\
\text { Kecil }\end{array}$ \\
& Tutupan Lahan & Foto Udara Format \\
3 & Jarak Longsor dengan & Kecil \\
& Sungai & DEM Terra SAR \\
4 & Kemiringan & DEM Terra SAR \\
5 & Ketinggian & DEM Terra SAR \\
6 & Bentuk Lereng & DEM Terra SAR \\
7 & Plan Curvature & DEM Terra SAR \\
8 & Profil Curvature & DEM Terra SAR \\
9 & Compound Topographic & \\
& Index(CTI) & DEM Terra SAR \\
10 & Topographic Position Index & \\
& (TPI) & \\
\hline
\end{tabular}

HASIL DAN PEMBAHASAN

Metode Interpretasi Foto Udara Format Kecil untuk Identifikasi Longsor Skala 1:10.000

Foto udara format kecil merupakan salah satu data penginderaan jauh yang dapat digunakan untuk mengetahui informasi topografi tanpa kontak langsung dengan objek (Aber et al., 2010). Foto udara format kecil memberikan informasi kenampakan lahan, sehingga foto udara format kecil dapat dijadikan 
sebagai data penginderaan jauh untuk identifikasi longsor. Foto udara format kecil memiliki ciri kenampakan tertentu yang dapat dijadikan sebagai kunci untuk membangun metode interpretasi untuk identifikasi longsor. Foto udara format kecil untuk identifikasi longsor menggunakan sembilan unsur interpretasi. Menurut Sutanto (1986), hasil interpretasi foto udara harus dilakukan uji akurasi melalui survei lapangan, sehingga hasil interpretasi dapat dibandingkan dengan kondisi sebenarnya di lapangan. Foto udara format kecil yang digunakan untuk membangun metode interpretasi untuk identifikasi longsor merupakan foto udara format kecil 2D.

Metode interpretasi foto udara format kecil untuk identifikasi longsor menggunakan metode stepwise, yaitu metode yang dilakukan berdasarkan langkahlangkah sistematis identifikasi longsor secara umum hingga khusus untuk setiap bagian longsor. Identifikasi longsor secara umum, yaitu mengidentifikasi karakteristik area terpengaruh longsor dan tidak terpengaruh longsor. Identifikasi longsor secara khusus, yaitu mengidentifikasi bagian-bagian longsor yang terdapat di area terpengaruh longsor. Proses identifikasi longsor dilakukan berdasarkan kenampakan objek pada foto udara. Proses identifikasi kenampakan objek pada foto udara untuk identifikasi longsor dilakukan secara sistematis tidak dapat dibolak balik. Proses identifikasi kenampakan objek pada foto udara menggunakan sembilan kunci interpretasi.

Metode interpretasi foto udara format kecil menggunakan teknik interpretasi visual on-screen 2D. Perbesaran dan perkecilan citra dilakukan berdasarkan output skala pemetaan. Teknik perbesar dan perkecil peta dipengaruhi oleh output peta yang dihasilkan karena berhubungan dengan Minimum Legible Area (MLA) untuk pemetaan. Berikut merupakan penjelasan detil identifikasi kunci interpretasi foto udara format kecil untuk identifikasi longsor menggunakan metode stepwise.

\section{Langkah 1 Identifikasi Area Longsor}

Identifikasi untuk area longsor, meliputi identifikasi longsor aktif dan identifikasi longsor tidak aktif. Pencapaian penelitian identifikasi longsor berdasarkan interpretasi foto udara format kecil sebagian besar berbasis kolaborasi kenampakan foto udara format kecil dengan kondisi morfologi lahan. Pencapaian penelitian untuk identifikasi longsor sebagian besar menggunakan foto udara format kecil stereo (3D), stereo temporal, menggunakan data ketinggian berupa kontur, sehingga identifikasi longsor berdasarkan morfologi permukaan lahan.

Penelitian ini mencoba menambahkan karakteristik kenampakan objek foto udara format kecil untuk identifikasi longsor dan unsur-unsur interpretasi untuk mengidentifikasi keaktifan, tipologi dan unit longsor. Identifikasi longsor berdasarkan karakterisik kenampakan objek foto udara berupa perimeter longsor, bentuk longsor, erosi parit, bidang gawir, tutupan lahan, pola vegetasi, asosiasi jalan dan asosiasi sungai. Unsur interpretasi yang digunakan berupa rona/warna, bentuk, asosiasi, pola, bayangan, dan tinggi.

\section{a. Berdasarkan Tutupan Lahan}

Identifikasi awal area longsor dapat di interpretasi berdasarkan rona/warna permukaan tanah dan tutupan lahan. Rona/warna permukaan tanah dan tutupan lahan antara longsor aktif dan longsor tidak aktif berbeda. Longsor aktif memiliki rona permukaan tanah sedikit terang dengan warna coklat. Rona/warna longsor aktif memberikan gambaran bahwa lahan yang mengalami longsor aktif permukaan tanah teraduk, sehingga vegetasi jarang dan permukaan tanah terlihat berwarna coklat. Longsor aktif sebagian besar memiliki tutupan lahan berupa vegetasi sengon, bambu, mahoni, ketela, semak dan kelapa, kerapatan renggang dan memiliki ketinggian 5-10 meter (Gambar 2a). Pemukiman tidak ditemukan pada area longsor aktif

Longsor tidak aktif membentuk pola tanam vegetasi sejajar perimeter longsor dan membentuk teras. Pola tanam vegetasi perimeter longsor dan membentuk teras mengindikasikan bahwa longsor tidak aktif memiliki bidang gawir mayor dan bidang gawir minor (Gambar 2b). Pola tanam vegetasi sengon, kelapa dan mahoni yang memiliki ketinggian lebih dari 10 meter yang berada pada bidang gawir longsor bertujuan untuk mengurangi pergerakan material tanah. Tutupan lahan berupa vegetasi sengon, kelapa dan mahoni yang berada di perimeter longsor memiliki ukuran tinggi pohon lebih dari 10 meter, sehingga terbentuk bayangan yang lebih gelap daripada vegetasi yang berada di sekitarnya.

\section{b. Bidang Gawir Longsor}

Bidang gawir merupakan bagian dari longsor. Bidang gawir merupakan bidang gelincir longsor yang tegak lurus dengan perimeter longsor. Bidang gawir longsor dapat diidentifikasi berdasarkan interpretasi foto udara format kecil, namun tidak semua bidang gawir longsor dapat diinterpretasi. Bidang gawir longsor yang dapat diidentifikasi berdasarkan interpretasi foto udara menunjukkan bahwa longsor merupakan longsor aktif dalam (deep active landslide). Bidang gawir longsor aktif dapat diinterpretasi berdasarkan unsur interpretasi berupa warna, bentuk dan asosiasi. Unsur interpretasi bidang gawir longsor aktif memiliki rona sedikit terang, warna kecoklatan, 
berbentuk lengkung membulat dan berasosiasi dengan vegetasi campuran dengan kerapatan sedang hingga renggang (Gambar 2c)

Bidang gawir longsor tidak aktif dapat diidentifikasi berdasarkan pola tanam dan bayangan vegetasi sengon, kelapa, dan mahoni yang memiliki ketinggian lebih dari 10 meter. Unsur interpretasi bayangan vegetasi yang terletak di bidang gawir longsor tidak aktif terjadi karena longsor tidak aktif merupakan longsor yang tidak bergerak lebih dari 12 bulan, sehingga berpengaruh terhadap tinggi dan umur vegetasi. Ukuran tinggi vegetasi menyebabkan terbentuknya bayangan (Gambar 2b).

\section{c. Bentuk Longsor}

Longsor memiliki bentuk melengkung memanjang yang terdapat di sepanjang perimeter dan igir longsor. Unsur interpretasi yang digunakan untuk mengidentifikasi bentuk longsor yaitu bayangan vegetasi sengon, kelapa dan mahoni. Vegetasi sengon, kelapa dan mahoni memiliki ukuran lebih tinggi dibandingkan vegetasi yang berada di badan longsor, sehingga menyebabkan terbentuknya pola dan bayangan vegetasi. Bentuk longsor aktif dan longsor tidak aktif memiliki persamaan, yaitu berbentuk melengkung memanjang (Gambar 2).

\section{d. Erosi Parit}

Erosi merupakan proses pelepasan, pengangkutan dan pengendapan material tanah yang dikontrol oleh sumber tenaga erosi. Erosi dapat menjadi inisiasi longsor dan erosi dapat disebabkan oleh longsor. Erosi menjadi inisiasi longsor, jika erosi merupakan erosi parit dan membentuk rekahan-rekahan tanah. Erosi parit dan rekahan tanah memperbesar air untuk meresap ke dalam tanah dan menambah beban massa tanah (Gambar 2c).

Erosi parit dapat diidentifikasi berdasarkan unsur interpretasi tinggi vegetasi, bayangan, bentuk, dan asosiasi. Tinggi vegetasi yang berbeda dengan sekitarnya menyebabkan terbentuknya bayangan vegetasi. Bentuk erosi parit yaitu memanjang mengikuti arah aliran air. Erosi parit sebagian besar berasosiasi dengan badan longsor dan igir longsor.

\section{e. Asosiasi Jalan dan Sungai}

Longsor aktif dapat diidentifikasi berdasarkan asosiasi jalan dan sungai. Jalan dan sungai DAS Bompon merupakan penggunaan lahan yang berpengaruh terhadap potensi longsor. Jalan dan sungai DAS Bompon sebagian besar memotong lereng, sehingga menyebabkan lereng tidak stabil. Asosiasi jalan dapat dijadikan sebagai indikator longsor aktif dan longsor tidak aktif. Perimeter longsor yang menghadap ke jalan dapat dijadikan indikator tipe jalan yang terkena longsor dan merupakan longsor aktif (Gambar 2e dan Gambar 2f) Longsor aktif yang berasosiasi dengan jalan dan sungai menunjukkan rona agak terang, warna coklat dan menunjukkan bentuk perimeter longsor. Jenis tutupan lahan berupa vegetasi semak belukar. Asosiasi jalan dan sungai dapat dijadikan sebagai indikator longsor aktif (Gambar 2).
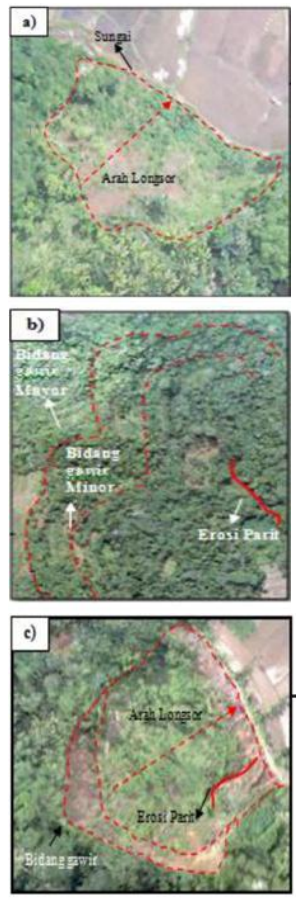

Identifikasi Bentuk dan Tutupan Vegetasi Longsor Aktif

Rona Badan Longsor : : sedikit terang

Warna : kecoklatan

Penggunaan Lahan : : kebun campuran

Vegetasi : kerapatan sedang hingga renggang

Tinggi Vegetasi : tidak terlalu tinggi (5-10 meter dan tidak menunjukkan bayangan)

\author{
Identifikasi Bentuk dan Tutupan Vegetasi Longsor Tidak Aktif \\ Rona Badan Longsor : : sedikit gelap \\ Warna : hijau tua \\ Penggunaan Lahan : : kebun campuran \\ Vegetasi \\ Tinggi Vegetasi \\ Pola \\ : dominasi sengon, kelapa, mahoni, dan bambu \\ : tinggi (> 10 meter dan menunjukkan bayangan) \\ : berteras menunjukkan bidan gawir mayot
}

\section{Identifikasi Bidang Gawir dan Erosi Parit}

Rona Badan Longsor : : sedikit terang

Rona Erosi Parit : : gelap (terdapat bayangan)

Warna Bidang Gawir : : kecoklatan (tidak terdapat vegetasi)

Rona Bidang Longsor : sedikit gelap

Warna : kehijauan

Vegetasi

Bentuk Longsor

: sedang hingga jarang

: curve 


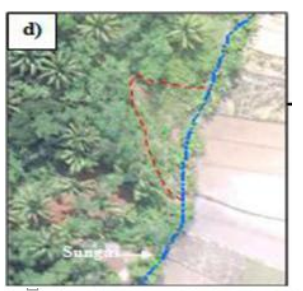

Identifikasi Asosiasi dengan Sungai untuk Longsor Tidak Aktif

- Berasosiasi dengan sungai

- Jenis vegetasi : semak belukar, sengon dengan tinggi 5- 10 meter

- Perimeter longsor menghadap sungai

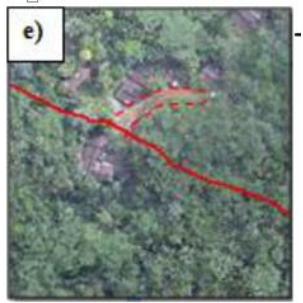

\section{Identifikasi Asosiasi dengan Jalan untuk Longsor Aktif}

Perimeter longsor menghadap ke jalan

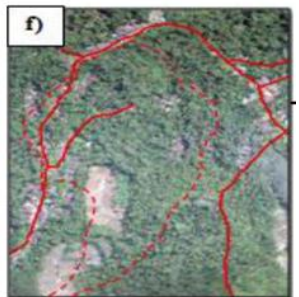

\section{Identifikasi Asosiasi dengan Jalan untuk Longsor Tidak Aktif}

Perimeter longsor berorientasi membelakangi jalan

Jenis vegetasi : sengon, kelapa, mahoni, dan bamboo dengan tinggi 10-17 meter

Terlihat zona depresi dan akumulasi

Gambar 2. Identifikasi Area Longsor Berdasarkan Kenampakan Objek pada Foto Udara dan Unsur Interpretasi

\section{Langkah 2 Identifikasi Tipologi Longsor}

\section{a. Karakteristik Pengolahan Lahan Pada Badan}

\section{Longsor}

Identifikasi tipologi longsor dapat dilakukan berdasarkan karakteristik kondisi lingkungan lahan yang mengalami longsor melalui survei lapangan dan interpretasi foto udara format kecil. Tipologi longsor DAS Bompon terdiri dari tipe longsor rotasional dan tipe longsor translasional. Badan longsor aktif maupun tidak aktif tipe rotasional DAS Bompon sebagian besar dimanfaatkan untuk lahan pertanian (Gambar 3b). Badan longsor aktif rotasional sebagian besar dimanfaatkan untuk lahan pertanian berupa ketela pohon, sengon, kelapa dengan ketinggian 5-10 meter. Vegetasi penutup lahan longsor aktif memiliki kerapatan renggang. Badan longsor tidak aktif rotasional dimanfaatkan untuk lahan pertanian kebun campuran dengan vegetasi semak, bambu, sengon, kelapa, dan mahoni yang memiliki ketinggian $>10$ meter . Badan longsor aktif translasional sebagian besar tidak dimanfaatkan karena badan longsor berbentuk planar, kemiringan terjal, dan material tanah relatif lebih tipis dibandingkan badan longsor rotasional. Identifikasi badan longsor dapat di lakukan berdasarkan pola tanam vegetasi. Longsor rotasional memiliki pola tanam vegetasi teratur, sedangkan longsor translasional memiliki pola tanam vegetasi yang terdispersi dengan jenis penutup lahan semak belukar (Gambar 3a).

\section{b. Berdasarkan Bentuk Perimeter Longsor}

Identifikasi tipologi longsor juga dapat dilakukan berdasarkan bentuk perimeter longsor. Longsor tipe rotasional memiliki bentuk perimeter longsor seperti mangkok, sedangkan longsor tipe translasional memiliki bentuk perimeter longsor planar. Unsur interpretasi untuk identifikasi bentuk perimeter longsor berdasarkan pola vegetasi yang terletak di perimeter longsor (Gambar 3).
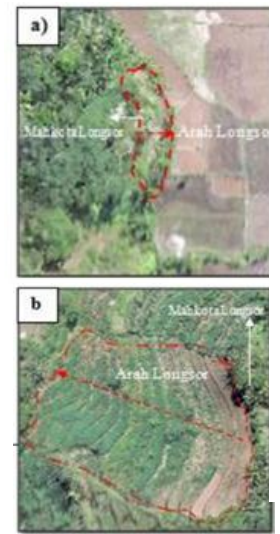

Identifikasi Tipologi Longsor Tradisionl

Perimeter Longsor : relative planar

Badan Longsor : planar

Badan longsor : tidak dimanfaatkan, vegetasi relative terdespersi (tidak beraturan)

Asosiasi : dekat dengan sungai atau jalan

Identifikasi Tipologi Longsor Rotasional

Perimeter Longsor : curve

Badan Longsor : curve

Badan longsor : : dimanfaatkan, vegetasi teratur)

Asosiasi : dekat dengan sungai atau jalan 


\section{Langkah 3 Identifikasi Bagian Badan Longsor \\ a. Bidang Gawir Mayor dan Bidang Gawir Minor}

Bidang gawir Mayor atau bidang gawir utama adalah zona pada ujung atas longsor yang berupa permukaan miring tajam dan zona pergerakan awal material longsor. Bidang gawir minor adalah zona pada bagian badan longsor yang berupa permukaan miring tajam sebagai indikator bahwa telah terjadi gerakan material sekunder. Bidang gawir Mayor dan Bidang gawir Minor merupakan indikator interpretasi untuk identifikasi zona deplesi. Bidang gawir mayor dan Bidang gawir minor dapat diidentifikasi berdasarkan interpretasi foto udara melalui pola vegetasi yang teratur dan bayangan vegetasi (Gambar 4b).

\section{b. Pemukiman dan Vegetasi}

Pola pemukiman dan vegetasi dalam area luasan longsor dapat dijadikan sebagai indikator untuk identifikasi zona akumulasi. Zona akumulasi merupakan zona terakumulasinya material longsor, sehingga pada zona ini lereng relatif lebih stabil dan tidak terdapat pergerakan material longsor. Pola pemukiman pada zona ini lebih padat dan terdispersi. Pola tanam vegetasi tidak menunjukkan keteraturan pola tanam seperti pada zona deplesi. Pola pemukiman yang padat dan pola tanam vegetasi yang tidak teratur menunjukkan bahwa lereng relatif lebih stabil (Gambar 4a).

Penyusunan metode interpretasi foto udara format kecil untuk identifikasi longsor diawali dengan pemahaman karakteristik topografi wilayah penelitian. Pemahaman karakteristik topografi wilayah meliputi pemahaman pemanfaatan lahan, jenis penutup lahan, aktifitas menusia yang mempengaruhi longsor dan proses-proses geomorfologi meliputi erosi dan longsor. Hasil pemahaman karakteristik topografi kemudian di cocokan dengan kenampakan foto udara format kecil.

Longsor sebagai proses pergerakan material tanah memiliki bagian-bagian longsor dan memiliki karakteristik kenampakan berdasarkan interpretasi foto udara format kecil. Bagian longsor dan karakteristik longsor yang dapat diidentifikasi berdasarkan interpretasi foto udara format kecil yaitu perimeter longsor, zona deplesi, zona akumulasi, bidang gawir, pemanfaatan badan longsor, tutupan vegetasi, asosiasi dengan jalan, asosiasi dengan sungai, dan bentuk longsor.

Hasil penggabungan pemahaman kerakteristik topografi wilayah dan foto udara format kecil menghasilkan dua kategori area, yaitu area yang terpengaruh longsor dan area yang tidak terpengaruh longsor. Fokus penyusunan metode interpretasi yaitu pada area yang terpengaruh longsor. Konsep metode stepwise untuk identifikasi longsor yaitu dari identifikasi area longsor dari umum hingga khusus. Identifikasi longsor dari umum hingga khusus dimulai dari pengidentifikasi area longsor hingga keaktifan dan tipologi longsor. Identifikasi longsor dari umum hingga khusus menggunakan kunci-kunci interpretasi.

Hasil inventori longsor menggunakan metode stepwise dilakukan uji akurasi dengan hasil inventori longsor melalui survei lapangan. Gambar 5 menunjukkan diagram alir metode stepwise untuk identifikasi longsor berdasarkan interpretasi foto udara format kecil.

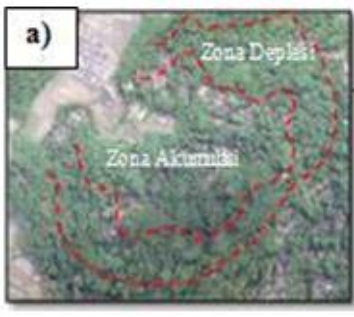

Identifikasi Zona Depresi

- Terdapat bidang gawir mayor dan minor yang diidentifikasi berdasarkan pola vegetasi

Perimeter bidang gawir mayor dan minor terlihat bayangan vegetasi

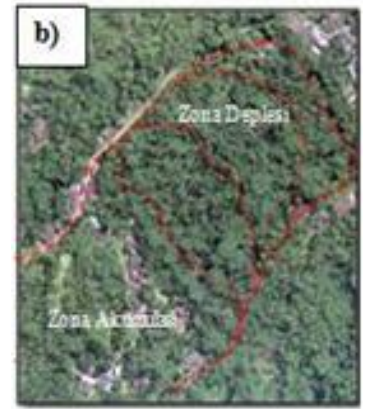

\author{
Identifikasi Zona Akumulasi \\ Pola permukiman terlihat padat (stabil) \\ Berasosiasi dengan jalan \\ Pola vegetasi terdispersi
}

Gambar 4. Identifikasi Bagian Badan Longsor 


\section{Sebaran Spasial Longsor Berdasarkan Tipe dan Keaktifan Longsor dari Interpretasi Foto Udara Format Kecil}

Data inventori longsor merupakan bagian penting untuk analisis kerawanan longsor. Data inventori longsor sebagian besar diperoleh melalui survei lapangan. Data inventori longsor dalam penelitian ini diperoleh berdasarkan interpretasi foto udara format kecil skala 1:10.000 dan didukung survei lapangan. Data inventori longsor DAS Bompon hasil interpretasi foto udara format kecil berupa tipologi longsor, keaktifan longsor, dan unit longsor.

Identifikasi longsor berdasarkan interpretasi foto udara format kecil menggunakan sembilan unsur interpretasi. Identifikasi longsor berdasarkan interpretasi menghasilkan 17 longsor tidak aktif tipe rotasional, 14 longsor aktif dengan tipe rotasional dan 4 longsor aktif dengan tipe translasional.

Gambar 6 menunjukkan hasil pemetaan sebaran spasial longsor DAS Bompon yang direpresentasikan menggunakan area dan titik. Penggunaan area dan titik untuk merepresentasi sebaran spasial longsor DAS Bompon karena beberapa longsor tidak memenuhi standart minimal area pemetaan (Minimum Legible Area). Menurut (Vink dalam Rossiter, 1999) luas minimum area yang dapat dipetakan dalam peta yaitu $0.25 \mathrm{~cm}^{2}$. Luas minimum yang dapat dipetakan berdasarkan output skala pemetaan 1:10.000 yaitu $2.500 \mathrm{~m}^{2}$, sehingga area longsor yang luasnya tidak memenuhi luas standar minimal pemetaan di representasikan dalam peta menggunakan titik.

Gambar 6 menunjukkan sebaran spasial longsor tidak aktif tipe rotasional lebih banyak di bagian hulu daripada hilir, sedangkan longsor aktif dengan tipe rotasional lebih banyak di hilir daripada hulu. Identifikasi keaktifan longsor berdasarkan kenampakan foto udara format kecil berdasarkan kerapatan tutupan lahan, pola tanam vegetasi, asosiasi jalan dan asosiasi sungai. Kerapatan tutupan dan pola vegetasi DAS Bompon bagian hulu dan bagian hilir berbeda. Perbedaan pola tutupan vegetasi mempengaruhi hasil interpretasi longsor dan unit longsor, sehingga setiap longsor memiliki perbedaan luas unit longsor.

\section{a. Uji Akurasi}

Uji akurasi merupakan bagian penting dalam penyajian data hasil interpretasi. Uji akurasi bertujuan untuk mengetahui tingkat ketelitian dan kebenaran hasil interpretasi foto udara dengan kondisi aktual di lapangan. Tabel 2 menunjukkan nilai hasil uji akurasi keseluruhan identifikasi longsor berdasarkan interpretasi foto udara yaitu 90\%. Hasil uji akurasi telah memenuhi batas minimal interpretasi dapat diterima, yaitu $85 \%$.

\section{b. Parameter Kerawanan Longsor}

Kejadian longsor lahan dipengaruhi oleh beberapa faktor penyebab longsor. Kejadian longsor dapat diketahui berdasarkan interpretasi foto udara format kecil. Kejadian longsor dipengaruhi oleh beberapa faktor penyebab longsor, seperti pemanfaatan penutup lahan, faktor yang berhubungan dengan hidrologi, aktifitas manusia dan morfologi permukaan lahan (Tabel 3 dan Gambar 7).

\section{c. Analisis Kerawanan Longsor}

Analisis kerawanan longsor menjelaskan nilai Frequency Ratio (FR) parameter pemicu longsor, sebaran kerawanan longsor, uji validitas peta kerawanan longsor, dan diagram alir metode Frequency Ratio (FR) sebagai metode pembuatan peta kerawanan longsor. Kelas kerawanan longsor DAS Bompon dibagi menjadi tiga kelas, yaitu kelas kerawanan tinggi (27.43\%), kelas kerawanan sedang (52.13\%), dan kelas kerawanan rendah (20.44\%).

Distribusi kelas kerawanan longsor rendah di DAS Bompon sebagian besar terletak pada unit morfologi puncak bukit dan sebagian kecil di dataran aluvial dan koluvial. Distribusi kelas kerawanan rendah DAS Bompon yang terletak pada unit morfologi puncak bukit, dataran aluvial dan dataran koluvial karena topografi pada bagian puncak bukit, dataran aluvial dan dataran koluvial berupa dataran, sehingga tidak ada energi untuk menggerakkan material.

Distribusi kerawanan sedang sebagian besar terletak pada unit morfologi lereng atas hingga lereng bawah. Distribusi kerawanan sedang terletak pada unit morfologi lereng atas hingga lereng bawah, karena unit lereng atas dan lereng bawah merupakan zona pergerakan material tanah. Faktor penyebab lain yaitu, unit morfologi lereng atas hingga lereng bawah dimanfaatan untuk lahan pertanian kebun campuran dengan teknik terasiring dengan vegetasi berkayu, sehingga memicu terjadinya pergerakan material. Jenis keaktifan dan tipologi longsor yang terdapat pada unit morfologi lereng atas hingga lereng bawah sebagian besar merupakan longsor tidak aktif rotasional, namun berpotensi terjadi reaktifasi longsor jika kestabilan lereng terganggu.

Distribusi kelas kerawanan tinggi mengikuti pola aliran sungai, berdekatan dengan jalan dan sebagian terletak secara terdispersi di unit morfologi lereng atas hingga lereng bawah. Penyebab tingginya kelas kerawanan longsor yang berdekatan dengan jalan karena pengaruh pemotongan lereng untuk jalan dan pengaruh getaran kendaraan yang dapat mempengaruhi potensi pergerakan material. Distribusi kelas kerawanan tinggi juga sebagian besar terdistribusi 
di bagian hilir DAS Bompon, karena bagian hilir merupakan pertemuan dengan anak sungai, sehingga mempengaruhi kecepatan aliran sungai. Gambar 8 merupakan sebaran kerawanan longsor DAS Bompon.

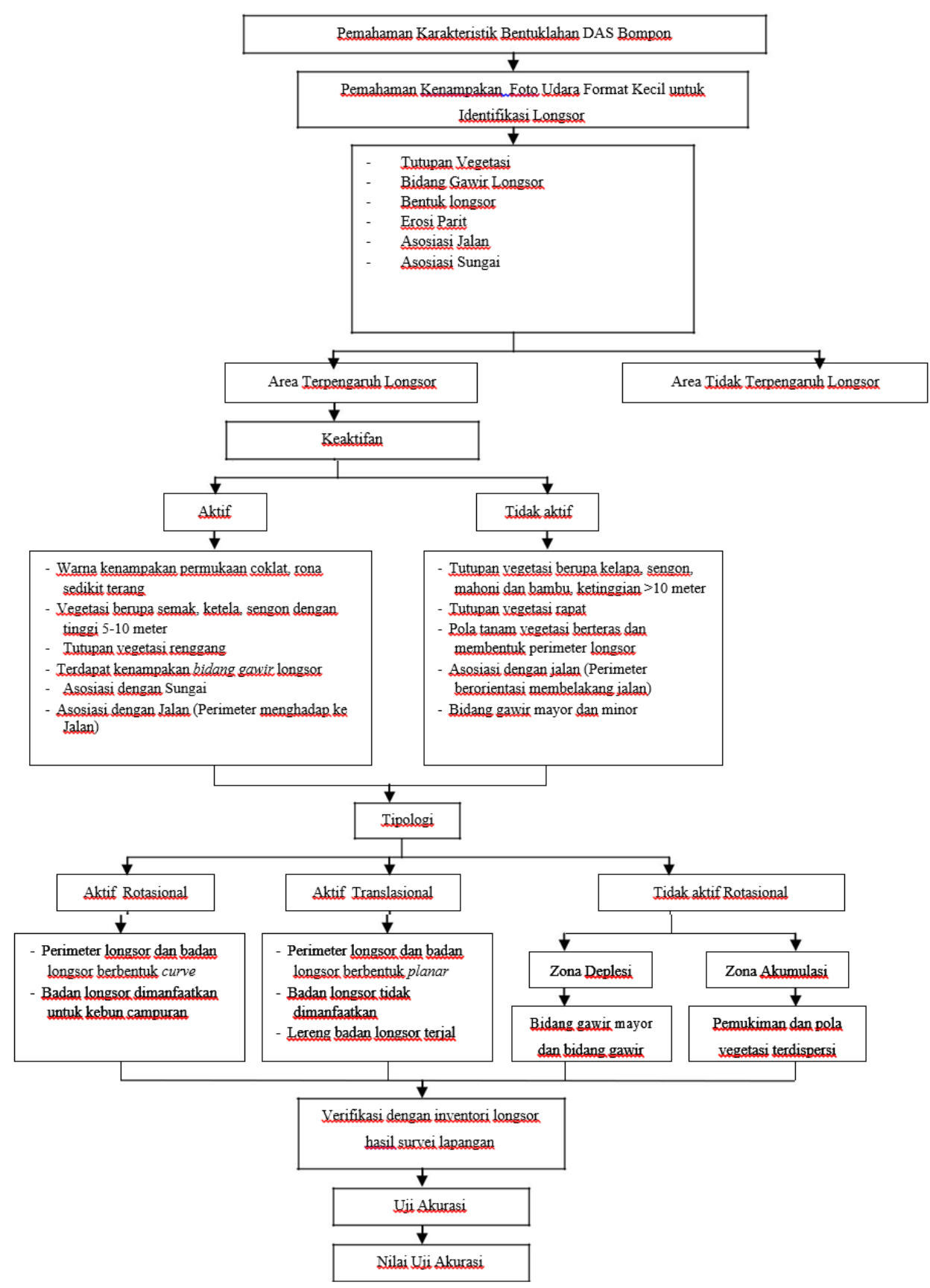

Gambar 5. Diagram Alir Metode Stepwise untuk Identifikasi Longsor Menggunakan Foto Udara Format Kecil Skala 1:10.000 


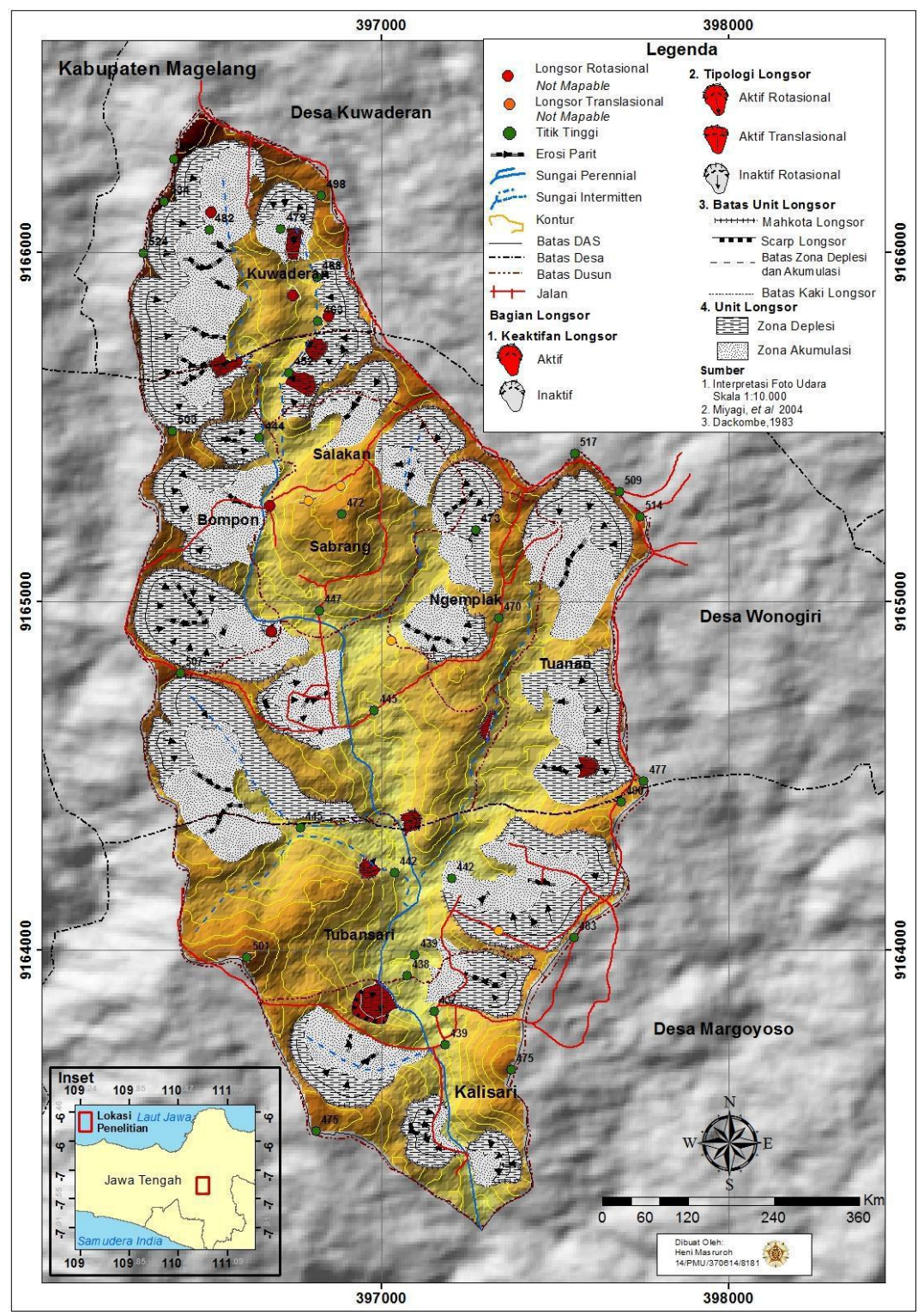

Gambar 6. Distribusi Spasial Longsor Berdasarkan Interpretasi Foto Udara Format Kecil

Tabel 2. Tabel Uji Akurasi Longsor Hasil Interpretasi Foto Udara Format Kecil

\begin{tabular}{|c|c|c|c|c|c|c|c|c|c|}
\hline \multirow[b]{2}{*}{ Data Lapangan } & \multirow[t]{2}{*}{ Foto Udara } & \multicolumn{8}{|c|}{ Data Foto Udara } \\
\hline & & $\begin{array}{c}\text { Aktif } \\
\text { Rotasional }\end{array}$ & $\begin{array}{c}\text { Aktif } \\
\text { Translasional }\end{array}$ & $\begin{array}{c}\text { Inaktif } \\
\text { Zona } \\
\text { Deplesi }\end{array}$ & $\begin{array}{l}\text { Zotasional } \\
\text { Zona } \\
\text { Akumulasi }\end{array}$ & $\begin{array}{c}\text { Tidak } \\
\text { Teridentifikasi }\end{array}$ & Total & $\begin{array}{l}\text { Omisi } \\
(\%)\end{array}$ & $\begin{array}{c}\text { Eror } \\
\text { Omisi } \\
(\%) \\
\end{array}$ \\
\hline Aktif & & 13 & & & & 4 & 17 & 0.76 & 0.24 \\
\hline Rotasional & & & & & & & & & \\
\hline $\begin{array}{l}\text { Aktif } \\
\text { Translasional }\end{array}$ & & & 4 & & & & 4 & 1 & 0 \\
\hline Inaktif & $\begin{array}{l}\text { Zona } \\
\text { Deplesi }\end{array}$ & & & 240 & & & 246 & 0.98 & 0.02 \\
\hline Rotasional & $\begin{array}{l}\text { Zona } \\
\text { Akumulasi }\end{array}$ & & & & 208 & & 219 & 0.95 & 0.05 \\
\hline $\begin{array}{l}\text { Tidak } \\
\text { Teridentifikasi }\end{array}$ & & 4 & 4 & 15 & 8 & & 31 & & \\
\hline Total & & 17 & 8 & 266 & 222 & 4 & 517 & & \\
\hline Omisi (\%) & & 0.76 & 0.5 & 0.9 & 0.94 & & & & \\
\hline $\begin{array}{l}\text { Eror Komisi } \\
(\%)\end{array}$ & & 0.24 & 0.5 & 0.1 & 0.006 & & & & \\
\hline & & & Akurasi & eseluruha & 0.90 & & & & \\
\hline
\end{tabular}


Tabel 3. Parameter Longsor

\begin{tabular}{|c|c|c|c|}
\hline Tipe Data & $\begin{array}{c}\text { Peta Tematik } \\
\text { Penyebab Longsor }\end{array}$ & Sumber & Pengaruh \\
\hline Data yang Berhubungan & $\triangle \quad$ Penutup Lahan & Interpretasi Foto & Pemanfaatan Penutup Lahan \\
\hline dengan Pemanfaatan & 凶 Jarak Longsor dengan & Udara & Berpengaruh terhadap Potensi \\
\hline Penutup Lahan & Sungai & & Pergerakan Material. \\
\hline \multirow[t]{4}{*}{$\begin{array}{l}\text { Data yang Berhubungan } \\
\text { dengan Longsor }\end{array}$} & Luas longsor & $\begin{array}{l}\text { Interpretasi Foto } \\
\text { Udara }\end{array}$ & Distribusi Longsor \\
\hline & Ketinggian & DEM Terra SAR & Potensi Energi Material Bergerak \\
\hline & Bentuk Lereng & DEM Terra SAR & Potensi Material Bergerak \\
\hline & Kemiringan Lereng & DEM Terra SAR & Kecepatan Energi Material bergerak \\
\hline $\begin{array}{l}\text { Data yang Berhubungan } \\
\text { dengan Kondisi }\end{array}$ & $\begin{array}{l}\text { Posisi Topografi (Unit } \\
\text { Morfologi) }\end{array}$ & DEM Terra SAR & $\begin{array}{l}\text { Potensi dan Kecepatan Material } \\
\text { Bergerak }\end{array}$ \\
\hline \multirow[t]{2}{*}{ Topografi } & Plan Curvature & DEM Terra SAR & $\begin{array}{l}\text { Menyebar dan mengumpulnya aliran } \\
\text { air }\end{array}$ \\
\hline & Profile Curvature & DEM Terra SAR & $\begin{array}{l}\text { Kecepatan dan kelambatan air } \\
\text { mengalir }\end{array}$ \\
\hline $\begin{array}{l}\text { Data yang Berhubungan } \\
\text { dengan Kondisi } \\
\text { Hidrologi }\end{array}$ & $\begin{array}{l}\text { Compound Topographic } \\
\text { Index }(\mathrm{CTI})\end{array}$ & DEM Terra SAR & Pengaruh kadar air tanah \\
\hline
\end{tabular}

Sumber : Modifikasi Samudra (2014)

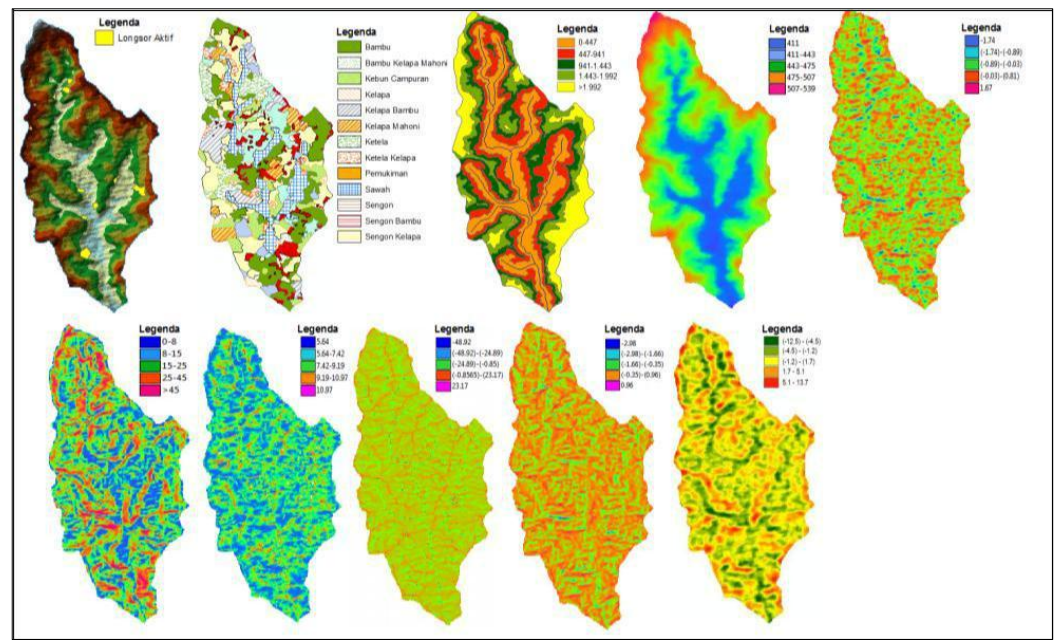

Gambar 7. Peta Tematik Parameter Longsor (a)Longsor Aktif; (b)Penutup Lahan; c)Jarak Longso dengan Sungai; (d) Ketingian;(e) Bentuk Lereng; (f) Kemiringan; (g) Compound Topographic Index (CTI); (h) Plan Curvature; (i) Prof Curvature; (j) Topographic Position Index 


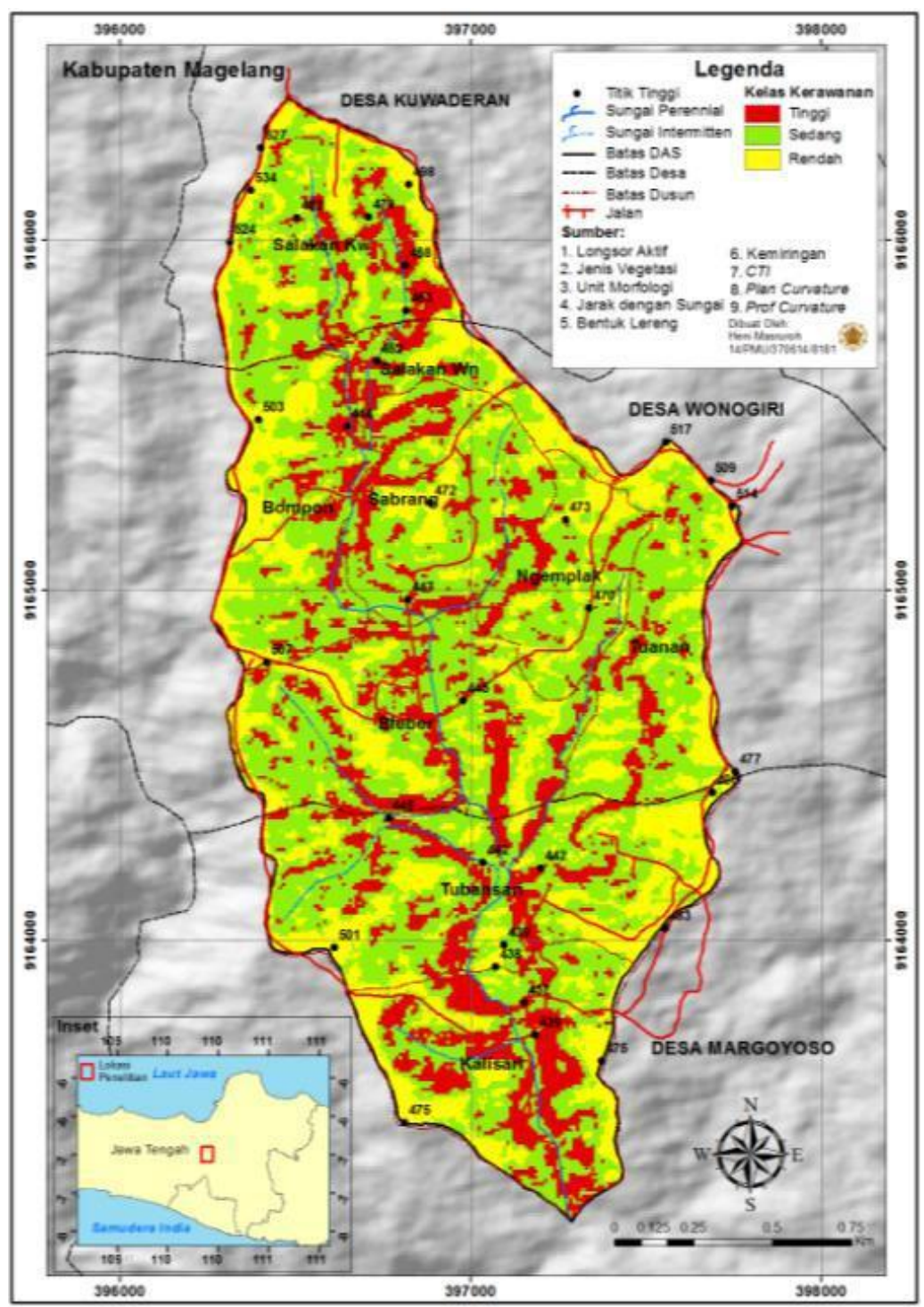

Gambar 8. Sebaran Distribusi Kerawanan Longsor DAS Bompon

\section{KESIMPULAN}

1. Foto udara format kecil dapat digunakan untuk identifikasi longsor. Kenampakan objek foto udara format kecil untuk identifikasi longsor berupa tutupan lahan, bidang gawir longsor, bentuk longsor, erosi parit, asosiasi jalan dan asosiasi sungai. Teknik yang digunakan untuk identifikasi longsor, yaitu teknik langkah demi langkah (stepwise method). Nilai uji akurasi identifikasi longsor berdasarkan interpretasi foto udara format kecil, yaitu 90\%.

2. Kerawanan longsor DAS Bompon terdiri dari tiga kelas kerawanan, yaitu kelas kerawanan tinggi 20.44\%, kelas kerawanan sedang 52.13\% dan kelas kerawanan rendah $27.43 \%$. Kerawanan longsor DAS Bompon disebabkan oleh pengaruh kecepatan aliran air yang mengerosi secara lateral pada bagian kaki lereng, sehingga menyebabkan lereng tidak stabil. Nilai akurasi peta kerawanan longsor DAS Bompon, yaitu 74\%.

\section{DAFTAR PUSTAKA}

Aber, J., Marzolf, I., dan Ries, J. (2010). Small Aerial Photography Principles, Technique, and Geoscience Applications. Oxford: Elsevier.

BNPB. (2015). Data Kejadian Bencana Tanah Longsor. Badan Nasional Penanggulangan Bencana Nasional. Diakses 16 September 2015 dari http://dibi.bnpb.go.id.

Carrara, A., Cardinali, M., Guzzetti, F., dan Reichenbach, P. (1995). GIS Technology in Mapping Landslide Hazard. In: Carrara, A. and Guzzetti, F. (eds.), Geographical Information Systems in Assessing Natural Hazards, 135- 175.

Fiorucci., Cardinali.,C., Rossi., Mondini., Santurri., Ardizzone.,dan Guzzeti. (2011). Seasonal Landslide Mapping and Estimation of Landslide Mobilization Rates Using Aerial and Satellite Images. Geomorphology, 59-70. 
Hadmoko, D. S., Lavigne, F., Sartohadi, J., Hadi, P., dan Winaryo. (2010). Landslide Hazard and Risk Assessment and Their Application in Risk Management and Landuse Planning in Eastern flank of Menoreh Mountains, Yogyakarta Province, Indonesia. Natural Hazard. 54, 623-642

Marfai, M. A., King, Lorenz., Singh, P.L., Mardiatno, D., Sartohadi, J., Hadmoko, D.S., dan Dewi, A. (2008). Natral Hazard in Central Java Province, Indonesia: an overview. Environmental Geology, 335-351.

Nichol, J. S., Shaker, Ahmed., dan Wong, S (2006). Application of high resolution stereo satellite images to detailed landslide hazard assessment. Geomorphology, 1-8.

Panizza, M. (1996). Environmental Geography.The Netherland: Elsevier Science. Rossiter, D. G. (1999). Soil Geographic Databases. Lecture Note International Institute for Aerospace Survey \& Earth Sciences (ITC), 1-42.
Samodra, G. (2014). Development of Risk Analysis Technique and Its Application to Geo Disaster Management in Indonesia. Dissertation. Japan: Kyusu University.

Sartohadi, J. (2008). The landslide Distribution in Loano Sub District Purworejo District, Central Java Province, Indonesia. Forum Geografi. 22 (2), 129144.

Strozzi, T., Ambrozzi, C., dan Raetzo, H. (2013). Interpretation of Aerial Photograph and Satellite SAR Interferometry for The Inventory of Landslide. Remote Sensing, 2554-2570.

Sutanto. (1986). Penginderaan Jauh Jilid I. Yogyakarta: Gadjah Mada University Press.

Van Westen., Mantovani, Fransco., dan Soeters, R. (1996). Remote Sensing Technique for Landslide Studies and Hazard Zonation in Europe. Geomorphology, 213-255. 